\title{
WISP-1 attenuates p53-mediated apoptosis in response to DNA damage through activation of the Akt kinase
}

\author{
Fei Su, Michael Overholtzer, Daniel Besser, and Arnold J. Levine ${ }^{1}$ \\ Laboratory of Cancer Biology, The Rockefeller University, New York, New York 10021-6399, USA
}

\begin{abstract}
WISP-1 (Wnt-1-induced secreted protein) was identified as an oncogene regulated by the Wnt-1- $\beta$-catenin pathway. WISP-1 belongs to the $\mathbf{C} C N$ family of growth factors, which are cysteine-rich, heparin-binding, secreted proteins associated with the extracellular matrix, and can interact with cellular integrins. Expression of WISP-1 in some cells results in transformation and tumorigenesis. Here it is shown that WISP-1 can activate the antiapoptotic Akt/PKB signaling pathway. It also is demonstrated that WISP-1 can prevent cells from undergoing apoptosis following DNA damage through inhibition of the mitochondrial release of cytochrome $c$ and up-regulation of antiapoptotic $B c l-X_{L}$. Furthermore, the results show that WISP-1 protects cells from p53-dependent cell death, but not Fas-ligand activated cell death, suggesting that there may be cross talk between the tumor suppressor protein p53 and WISP-1 signaling pathways. WISP-1 acts to block cell death at a late stage in the p53-mediated apoptosis pathway.
\end{abstract}

[Key Words: WISP-1; Akt; apoptosis; p53; DNA damage]

Received September 4, 2001; revised version accepted November 7, 2001.

WISP-1 (ㅁnt-1-induced secreted protein) was first identified as a downstream target gene of the Wnt-1- $\beta$ catenin signaling pathway using subtractive hybridization between the mouse mammary epithelial cell line C57MG and Wnt-1-expressing C57MG cells (Pennica et al. 1998). The WISP-1 gene is located on human chromosome 8q24.1-8q24.3 and encodes a protein of 367 amino acids with four potential N-linked glycosylation sites. WISP-1 genomic DNA is amplified in some human colon cancer cell lines, and its mRNA is overexpressed (2to $>30$-fold) in $84 \%$ of the human colon tumors examined as compared with patient-matched adjacent mucosa (Pennica et al. 1998). Recent studies have demonstrated that WISP-1 can accelerate cell proliferation and can morphologically transform cells. WISP-1 overexpressing cells, when injected into nude mice, form tumors (Xu et al. 2000).

WISP-1 is a member of the CCN family of growth factors, which are secreted, heparin-binding, cysteine-rich, and extracellular matrix-associated proteins, including CTGF (connective tissue growth factor), Cyr-61 (cysteine-rich 61), nov (nephroblastoma overexpressed), Cop1/WISP-2, and WISP-3 (Brigstock 1999). These highly conserved proteins share four cysteine-rich modular domains with sequence similarities to insulin-like growth

${ }^{1}$ Corresponding author.

E-MAIL alevine@rockvax.rockefeller.edu; FAX (212) 327-8900.

Article and publication are at http://www.genesdev.org/cgi/doi/10.1101/ gad.942902. factor-binding proteins (IGFBP), von Willebrand factor (VWC), thrombospondin (TSP), and growth factor cysteine knots (CT) (Lau and Lam 1999).

Two members of the CCN family, CTGF and Cyr61, signal through the integrin receptors $\alpha_{\mathrm{v}} \beta_{3}, \alpha_{\mathrm{IIb}} \beta_{3}, \alpha_{\mathrm{v}} \beta_{5}$, and $\alpha_{6} \beta_{1}$ (Kireeva et al. 1998; Babic et al. 1999; Jedsadayanmata et al. 1999; Chen et al. 2001; Grzeszkiewicz et al. 2001). Integrin receptors have been shown to play a role in cell migration and proliferation, and can affect cancer cell invasion and growth (Giancotti and Ruoslahti 1999; Ruoslahti 1999). It has been reported that integrins can signal through integrin-linked kinase (ILK) (Dedhar et al. 1999) or focal adhesion kinase (FAK) (Ruoslahti 1999) to activate downstream targets, such as Akt (Delcommenne et al. 1998; Sonoda et al. 1999; Persad et al. 2001). Akt, also known as protein kinase $\mathrm{B}(\mathrm{PKB})$, is a serine/ threonine kinase, which is phosphorylated and activated by a variety of growth and survival signals including insulin, epidermal growth-factor receptor (EGFR), plateletderived growth factor (PDGF), Ras, and Her2/neu. The Akt signaling pathway is negatively regulated by the PTEN tumor suppressor lipid phosphatase (Verdu et al. 1999; Di Cristofano and Pandolfi 2000). Activation of Akt promotes cell survival by inhibiting apoptosis through several downstream effectors. Bad, for example, which is normally a proapoptotic bcl-2 family member, releases the antiapoptotic Bcl-x following phosphorylation by Akt (Zha et al. 1996; Datta et al. 1997). Caspase9, an effector protein of the intrinsic cell-death machinery, can also be inactivated following Akt phosphoryla- 
tion (Cardone et al. 1998). The forkhead family of transcription factors, which normally function to upregulate the expression of proapoptotic proteins such as Fas ligand, is translocated from the nucleus to the cytoplasm following its phosphorylation by Akt (Brunet et al. 1999; Kops et al. 1999). Finally, the universal cell-cycle inhibitor $\mathrm{p} 21^{\mathrm{Cip} 1 / \mathrm{WAF} 1}$, has also been shown to relocalize into the cytoplasm following Akt phosphorylation to promote cell growth in Her2/neu-overexpressing cells and breast cancers (Zhou et al. 2001).

Most, if not all, apoptotic cell death signaling pathways ultimately lead to the activation of members of the caspase family of proteases. In general, activation of the caspase cascade requires both initiator caspases, such as caspase-8 and caspase-9, and effector caspases such as caspase-3 (Cryns and Yuan 1998; Nunez et al. 1998). There are two well-described pathways by which initiator caspases become activated. One of these pathways initiates at the plasma membrane where death receptor (such as Fas) and ligand binding results in activation of caspase-8 (Ashkenazi and Dixit 1998). In the second apoptotic pathway, cellular stress such as DNA damage causes the release of cytochrome $c$ from mitochondria. Cytochrome $c$, in association with a cytoplasmic protein known as Apaf-1 (appoptotic protease-activating factor 1), recruits caspase-9 and leads to caspase-9 activation $(\mathrm{Hu}$ et al. 1999). The active caspase-9, in turn, can process procaspase- 3 , and the activated caspase- 3 then cleaves several key cellular substrates such as PARP and DFF45, leading to apoptosis (Zou et al. 1997). Recently it was shown that, in irradiation- or oncogene-induced p53-dependent apoptosis, Apaf-1 and caspase- 9 were essential downstream targets of p53 (Soengas et al. 1999).

The p53 tumor-suppressor protein has at least two roles in preventing cancers: cell cycle arrest in $\mathrm{G}_{1}$, which allows time for the repair of damaged DNA, or apoptosis, which eliminates cells with damaged genomes (Ko and Prives 1996; Levine 1997). p53 can be activated by many types of stress, including DNA damage, oncogene activation, hypoxia, and loss of normal cell-cell contacts (Bates and Vousden 1999; Prives and Hall 1999), and the activation of p53-dependent apoptosis can contribute to the inhibition of cancer development at several stages during tumorigenesis (Lowe and Lin 2000). It has been well documented that the transcriptional activity of p53 is important in initiating apoptosis through such genes as Bax (Miyashita and Reed 1995), Noxa (E. Oda et al. 2000), p53AIP1 (K. Oda et al. 2000), KILLER/DR5 (Wu et al. 2000), PERP (Attardi et al. 2000), PIDD (Lin et al. 2000), and PUMA (Nakano and Vousden 2001; Yu et al. 2001). So far, it seems that there is no single gene that is the principal mediator of the p53-dependent apoptotic signal, and it has been suggested that different sets of p53 downstream target genes may be regulated coordinately dependent on the nature of the apoptotic stimulus (Zhao et al. 2000).

Recent results showed that overexpression of WISP-1 induced accelerated growth, morphological transformation of NRK-49F fibroblastic cells, and conferred tumorigenic potential on these cells (Xu et al. 2000). However, the mechanism by which WISP-1 promotes tumorigenicity is still unknown. In this study, the hypothesis that WISP-1 promotes tumorigenicity by suppression of p53regulated apoptotic pathway was tested. Evidence is provided that WISP-1 signaling inhibits cell death following DNA damage by activation of the prosurvival Akt pathway and the antiapoptotic Bcl- $\mathrm{X}_{\mathrm{L}}$, and by inhibition of the mitochondrial release of cytochrome $c$. Moreover, we find that WISP-1 signaling acts only against p53-dependent apoptosis because WISP-1 does not inhibit the cell death induced by DNA damage in p53-null cells. These studies suggest that WISP-1 promotes tumorigenicity not only by accelerating cell proliferation but also by the inhibition of programmed cell death.

\section{Results}

WISP-1 induces phosphorylation and activation of Akt

Akt promotes cell survival by inhibiting apoptosis via several possible downstream effectors, including phosphorylation and inactivation of Bad (Zha et al. 1996; Datta et al. 1997), inactivation of caspase-9 (Cardone et al. 1998) and repression of the forkhead transcription factor (Brunet et al. 1999). Because WISP-1 might bind to integrins like the other members of the CCN family, and because it has been shown that integrin engagement stimulates ILK/FAK activity leading to the activation of Akt (Delcommenne et al. 1998), we sought to determine whether WISP-1 is upstream of Akt, and may regulate its phosphorylation and activation. Because phosphorylation of Akt on Ser 473 is required for its activation, an antibody specific to phosphorylated Ser 473 was used to detect Akt activation by WISP-1. Serum starved normal rat kidney fibroblasts (NRK49F) were treated with either mock- or WISP-1-conditioned medium collected from NRK49F cells that express either no exogenous proteins (an empty vector) or human WISP-1, respectively, or with serum, which is known to activate Akt. Phosphorylation of Akt was detected by Western blotting of wholecell extracts with a phosphorylated Ser 473-specific antibody. As shown in Figure 1A, Akt was activated by WISP-1-conditioned medium $10 \mathrm{~min}$ after treatment, and this activation peaked at $30 \mathrm{~min}$ after adding the conditioned medium, whereas, in the cells that were treated with mock-conditioned medium, Akt activation was not observed (Fig. 1A).

It is possible that Akt activation by WISP-1-conditioned medium might be caused by other proteins or components in the conditioned media and not be a direct effect of WISP-1 signaling. To examine this possibility, WISP-1-conditioned medium was incubated with antiWISP-1-neutralizing antibody before addition to the serum-starved cells. As shown in Figure 1B, anti-WISP-1neutralizing antibody did abrogate the phosphorylation of Akt at Ser 473 in cells treated with WISP-1-conditioned medium, but had no effect on mock-conditioned medium or serum-treated cells, indicating that Akt activation by WISP-1-conditioned medium is inhibited by a neutralizing antibody specific against WISP-1 (Fig. 1B). It has been well documented that Wnt signaling in- 
$\mathbf{A}$

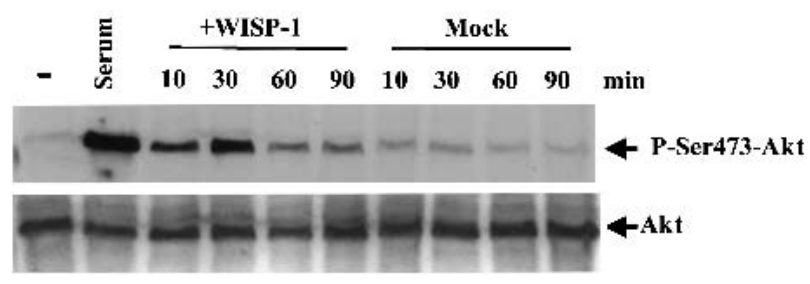

B

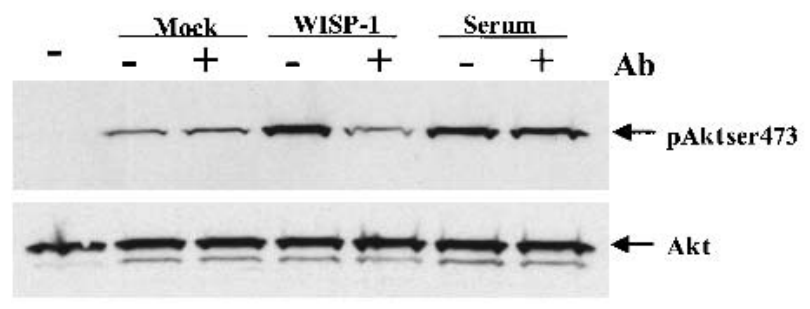

C

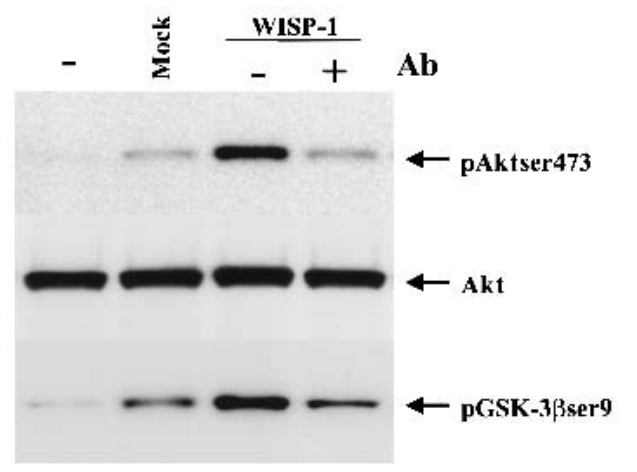

Figure 1. WISP-1 induces Akt activation. (A) Serum starved NRK-49F cells were incubated without (-) or with conditioned media collected from either mock infected (Mock) or WISP-1 (WISP-1) infected NRK-49F cells for the indicated time. Cells were also treated with $10 \%$ FBS (Serum). Whole-cell extracts were prepared and $50 \mu \mathrm{g}$ of lysate were subjected to Western analysis using antibodies against phosphorylated Ser 473 of Akt (p-Ser 473-Akt). The Western blot was stripped and probed with antibody against total Akt (Akt) to confirm that similar amounts of whole-cell extracts were analyzed. $(B, C)$ Before they were used to treat the cells, serum or conditioned media collected from either mock or WISP-1 infected NRK-49F cells were incubated with anti-WISP-1 antibody $(1: 100)$ at room temperature for $2 \mathrm{~h}$. Cells were harvested $30 \mathrm{~min}$ after the indicated treatments.

duces the phosphorylation and inactivation of the constitutively active glycogen synthase kinase $3 \beta$ (GSK3 $\beta$ ). This, in turn, no longer can phosphorylate $\beta$-catenin. Stabilized cytosolic $\beta$-catenin can translocate into the nucleus and form a complex with T-cell factor/lymphocyte enhancing factor (TCF/LEF) family of transcription factors to activate the expression of target genes, such as cyclin D1, c-Myc, and WISP-1, which are oncogenes and promote cell survival (Polakis 1999). Using conditioned medium, we also sought to test whether GSK3 $\beta$, a known specific Akt target (Cross et al. 1995), can be phosphorylated and inactivated by WISP-1. Again, serum-starved NRK49F cells were treated with mock- or WISP-1-conditioned media for $30 \mathrm{~min}$. Phosphorylation of GSK3 $\beta$ was detected by a specific antibody against Ser 9 of GSK3 $\beta$ in a Western analysis. As shown in Figure 1C, WISP-1-conditioned medium, but not the mock-conditioned medium, induced a strong phosphorylation of both Akt at Ser 473 and GSK3 $\beta$ at Ser 9, and this induction was abrogated by preincubation of the WISP-1 conditioned medium with an anti-WISP-1 neutralizing antibody. Taken together, these data demonstrate that WISP-1 indeed can induce phosphorylation and activation of the Akt kinase, and subsequent phosphorylation of GSK3 3 .

\section{WISP-1 inhibits apoptosis induced by DNA damage}

It has been shown that overexpression of WISP-1 can accelerate cell growth and induce transformation, and that WISP-1-overexpressing cells form tumors in nude mice (Xu et al. 2000). The experiments described here showed that WISP-1 activates Akt (Fig. 1). As mentioned previously, Akt is a proto-oncogene that stimulates cell survival by inhibiting apoptosis. We therefore investigated whether WISP-1 would inhibit apoptosis, and more specifically, p53-dependent apoptosis. Several H460 (human lung carcinoma cells containing wild-type p53) stable cell lines transfected with Flag-tagged WISP-1 were established. We induced apoptosis in these cells by means of DNA damage, such as UV irradiation, etoposide treatment, and $\gamma$-irradiation. Vector alone and FlagWISP-1-expressing $\mathrm{H} 460$ cells were treated with either UV or etoposide at the indicated dosages. As shown in Figure 2, UV and etoposide treatment caused high amounts of cell death in the mock-transfected cells; however, there is much reduced cell death in WISP-1expressing cells, indicating that WISP-1 can protect cells from apoptosis caused by DNA damage (Fig. 2A).

The percentage of apoptotic cells within a given population can be quantitated by labeling cells with propidium iodide, subjecting them to flow cytometric analysis, and calculating the percentage of cells with a sub- $\mathrm{G}_{1}$ DNA content. As indicated in Figure 2B, UV irradiation induced a significant amount of cell death $\left(35 \%\right.$ sub- $\left.\mathrm{G}_{1}\right)$, and etoposide treatment induced $\sim 30 \%$ apoptosis in mock-treated cells. However, the level of apoptosis was reduced in the WISP-1-expressing cells treated by UV irradiation $\left(11 \%\right.$ sub- $\left.\mathrm{G}_{1}\right)$, and the level of cell death was decreased to an even greater extent ( sixfold reduction) in the WISP-1-expressing cells treated with etoposide (Fig. 2B). To determine whether WISP-1 inhibition of apoptosis was a general observation and not cell typespecific, we used MCF-7 cells that are human breast adenocarcinoma cells that also express wild-type p53. As with $\mathrm{H} 460$ cells, two- to threefold inhibition of cell death by WISP-1 was observed in MCF-7 cells treated with $\gamma$-irradiation (Fig. 2C). These results confirm that WISP-1 indeed can attenuate cell death following DNA damage. 
A
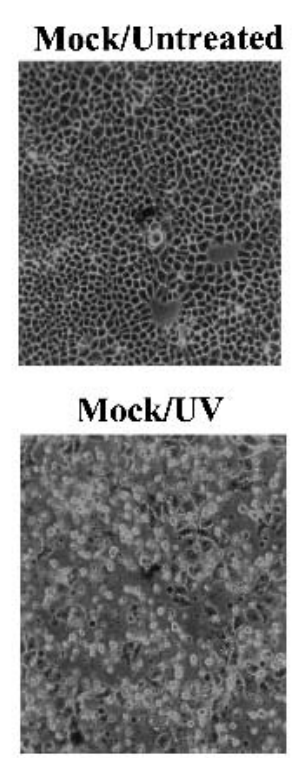

Mock/Etoposide

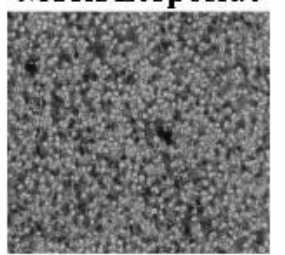

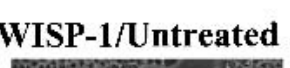
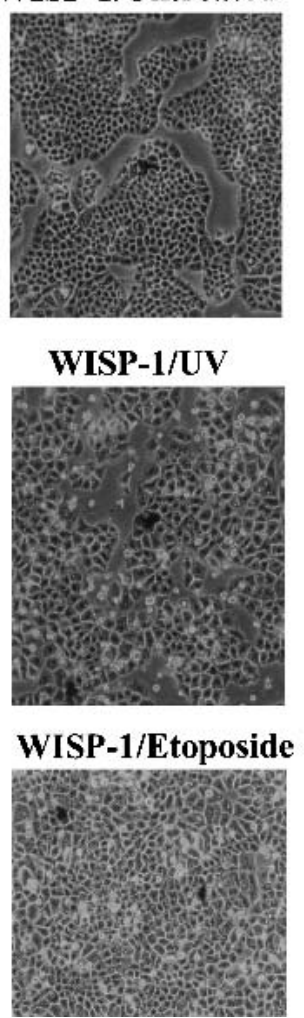

\section{B}

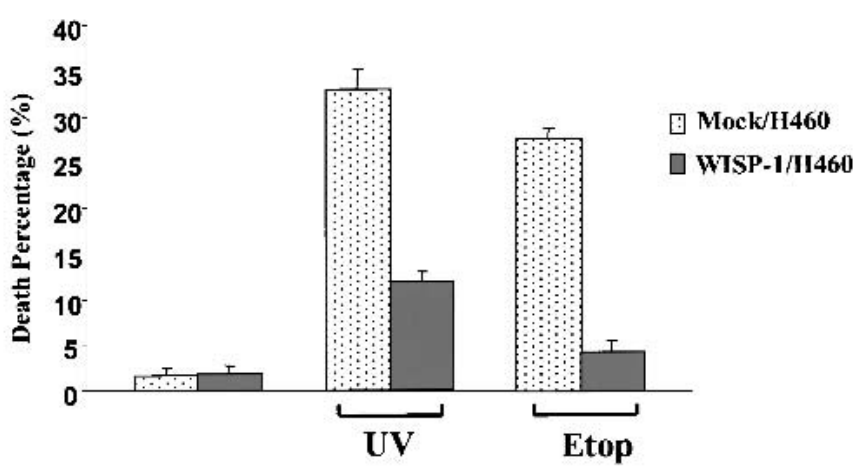

C

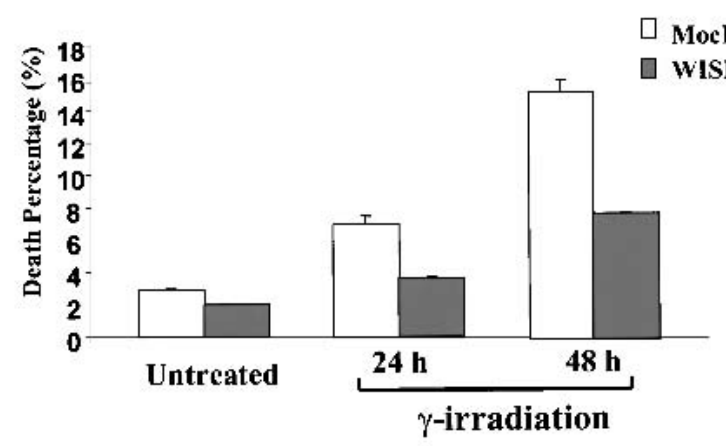

Figure 2. WISP-1 protects cells from apoptosis following DNA damage. (A) Phase contrast microscopy of mock or WISP-1-expressing H460 cells, $24 \mathrm{~h}$ after UV $\left(20 \mathrm{~J} / \mathrm{m}^{2}\right)$ or etoposide $(50 \mu \mathrm{M})$ (Etop) treatment. (B) Quantitative analysis of cell death. Vector (mock) or WISP-1-expressing $\mathrm{H} 460$ cells were treated as in A. Apoptosis percentage (sub-G $\mathrm{G}_{1}$ population) was measured by flow cytometry with propidium iodide staining. Data are means from four independent experiments. $(C)$ The percentile ratio of apoptotic MCF-7 cells following $\gamma$-irradiation (40 Gy) measured by flow cytometric analysis for sub- $\mathrm{G}_{1}$ population.

WISP-1 blocks the activation of caspase-3 and inhibits the cytochrome c release induced by DNA damage

Caspase activation is known to be a critical event in the induction of the cell death process. Among the members of the caspase family, caspase- 3 is a common and important effector of the apoptotic process. It is well documented that both caspase- 8 and caspase- 9 can activate caspase-3 in response to different death signals. Caspase-3 cleaves several important cellular substrates such as PARP and DFF45, leading to apoptosis (Nunez et al. 1998). We therefore examined whether the activation of caspase- 3 was inhibited by WISP-1. Caspase- 3 exists in normal cells as an inactive procaspase-3, p32. Upon death signals triggering the caspase cascade, procaspase- 3 is cleaved by caspase- 9 into an active form, which is p20/p17. Control and WISP-1-overexpressing cells were treated with etoposide or UV irradiation, and whole-cell lysates were subjected to Western blot analysis using an antibody against both forms of caspase-3. The cleaved, active form of caspase-3 (p20/p17) was observed in both etoposide and UV irradiation treated control cells (Fig. 3, lanes 3,5). However, the processing of procaspase- 3 was attenuated in the WISP-1-expressing cells treated with UV irradiation (Fig. 3, lane 4) and com- pletely abolished in the WISP-1-expressing cells treated with etoposide (Fig. 3, lane 6), indicating that WISP-1 signaling can inhibit the processing of procaspase-3. The observed cleavages of procaspase- 3 in this experiment correlate with the apoptosis data shown above (Fig. 2) where WISP-1 protected cells better from etoposide-induced apoptosis than UV-induced apoptosis.

The major mechanism of processing and activation of procaspases is mediated by the Apaf- 1 protein. Apaf- 1 is activated by binding to cytochrome $c$, which is released from mitochondria in response to various death stimuli (Zou et al. 1997). We therefore examined whether WISP-1 is capable of regulating the release of cytochrome $c$ from mitochondria. Cytosolic extracts were prepared $24 \mathrm{~h}$ after etoposide treatment, and cytochrome $c$ released from mitochondria to the S-100 cytosolic fraction was detected by immunoblotting. As shown in Figure $3 \mathrm{~B}$, etoposide treatment induced a dramatic release of cytochrome $c$ in the vector-expressing cells (Fig. 3B, lane 3), however, WISP-1 was able to block the release of cytochrome $c$ from mitochondria in response to DNA damage (Fig. 3B, lane 4). Taken collectively, these results indicate that WISP-1 signaling can inhibit the mitochondrial release of cytochrome $c$ and the subsequent activation of caspase- 3 . 
$\mathbf{A}$

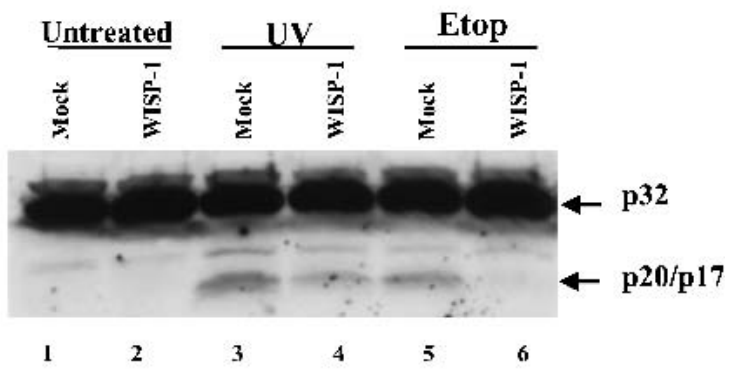

B

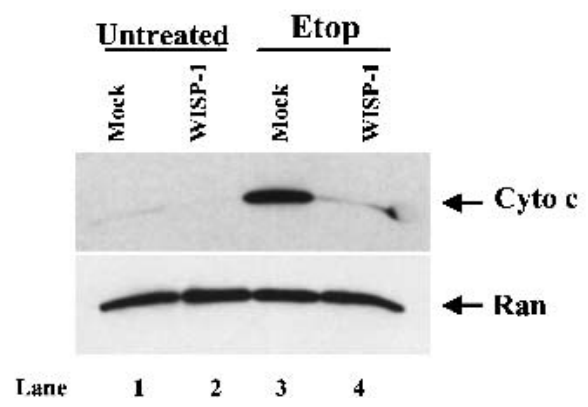

Figure 3. (A) WISP-1 blocks the activation of caspase- 3 induced by DNA damage. Vector or WISP-1 expressing H460 cells were either UV $\left(20 \mathrm{~J} / \mathrm{m}^{2}\right)$ irradiated or treated with $50 \mu \mathrm{M}$ of etoposide (Etop) for $24 \mathrm{~h}$. Expression and processing of caspase-3 were examined by Western blot analysis. (B) WISP-1 prevents the cytochrome $c$ release from mitochondria. Cytosolic extracts were prepared $24 \mathrm{~h}$ after the cells were treated with etoposide (Etop), the release of cytochrome $c$ from mitochondria was detected by Western blotting using a monoclonal antibody against cytochrome $c$. Anti-Ran blotting serves as an indication that the samples were loaded in similar amounts.

\section{WISP-1 cannot inhibit p53-independent apoptosis}

Because both $\mathrm{H} 460$ and MCF-7 cells express wild-type p53, and the level of p53 protein was elevated in both vector- and WISP-1-expressing cells following DNA damage, we attempted to determine whether WISP-1 can protect cells from apoptosis in the absence of p53. We overexpressed WISP-1 in H1299, a human lung carcinoma cell line that is null for p53. WISP-1 expressing H1299 cells showed accelerated cell growth compared with vector expressing cells (data not shown). Vectorand WISP-1-expressing $\mathrm{H} 1299$ cells were treated with 50 $\mu \mathrm{M}$ of etoposide for $24 \mathrm{~h}$; floating and attached cells were collected and subjected to FACS analysis with propidium iodide staining. The cells mock-transfected with vector were susceptible to etoposide induced cell death, with $\sim 9 \%$ of cells becoming apoptotic, and there was a similar level of cell death in WISP-1-expressing cells (Fig. 4). These data suggest that WISP-1 cannot protect cells against DNA damage-induced apoptosis in the absence of $\mathrm{p} 53$.

\section{WISP-1 does not protect cells from Fas-induced apoptosis}

As mentioned previously, there are two major apoptotic signaling pathways: One is signaling via stress, including
DNA damage, inducing p53 and cytochrome $c /$ Apaf-1/ caspase-9 pathway, and the other is signaling through death receptors such as Fas, and the caspase-8 pathway. Having demonstrated that WISP-1 can inhibit apoptosis following DNA damage, we next tested whether WISP-1 could prevent cells from death receptor-induced apoptosis. It has been well established that coupling of the cell surface receptor Fas with its natural ligand, Fas-ligand (FasL), triggers apoptosis (Nagata and Golstein 1995). This death pathway can also be triggered upon Fas crosslinking with the cytolytic monoclonal antibody $\mathrm{CH}-11$ (Nagata and Golstein 1995; Tanaka et al. 1996). Vector alone and WISP-1-expressing H460 cells were treated with anti-Fas monoclonal antibody $\mathrm{CH}-11$ at indicated concentrations. Thirty hours after treatment, cells were stained with Hoechst 33258 and the apoptotic percentage was determined by scoring condensed nuclei as apoptotic and diffuse staining as normal nuclei. As shown in Figure 5, there were similar amounts of cell death in both control and WISP-1-expressing cells treated with different concentrations of anti-Fas antibody, indicating that WISP-1 can not inhibit Fas-induced cell death (Fig. 5A). Similar results were obtained by calculating sub- $\mathrm{G}_{1}$ population using FACS analysis (data not shown). We also examined the cleavage product of an endogenous substrate of caspase-3, PARP, which is a marker of apoptosis. Vector alone or WISP-1-expressing cells were treated with $500 \mathrm{ng} / \mathrm{mL}$ of anti-Fas antibody for $30 \mathrm{~h}$, floating and attached cells were collected, and whole-cell lysates were prepared. A Western blot analysis was then carried out with antibody against PARP. As shown in Figure 5B, PARP was not cleaved in untreated vector or WISP-1-expressing $\mathrm{H} 460$ cells (Fig. 5B, lanes 1,2), but it was cleaved in both vector and WISP-1-expressing cells treated with anti-Fas antibody (Fig. 5B, lanes 3,4). Taken together, these results suggest that WISP-1 signaling can only protect against p53-mediated apoptosis, and not Fas-mediated apoptosis.

\section{Does WISP-1 act by blocking p53 activation?}

It has been well documented that p53 triggers apoptosis or causes cell-cycle arrest in response to DNA damage

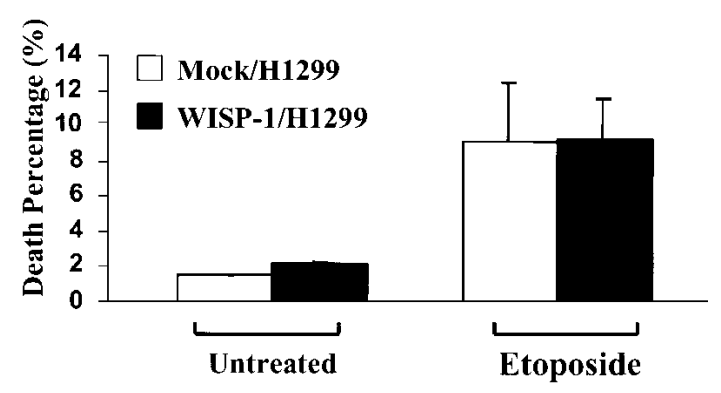

Figure 4. WISP-1 does not inhibit p53-independent apoptosis. Mock or WISP-1 transfected H1299 cells were seeded 24 h before treatment with $50 \mu \mathrm{M}$ of etoposide. Apoptotic percentage (sub-G $\mathrm{G}_{1}$ population) was measured by flow cytometry with propidium iodide staining. 


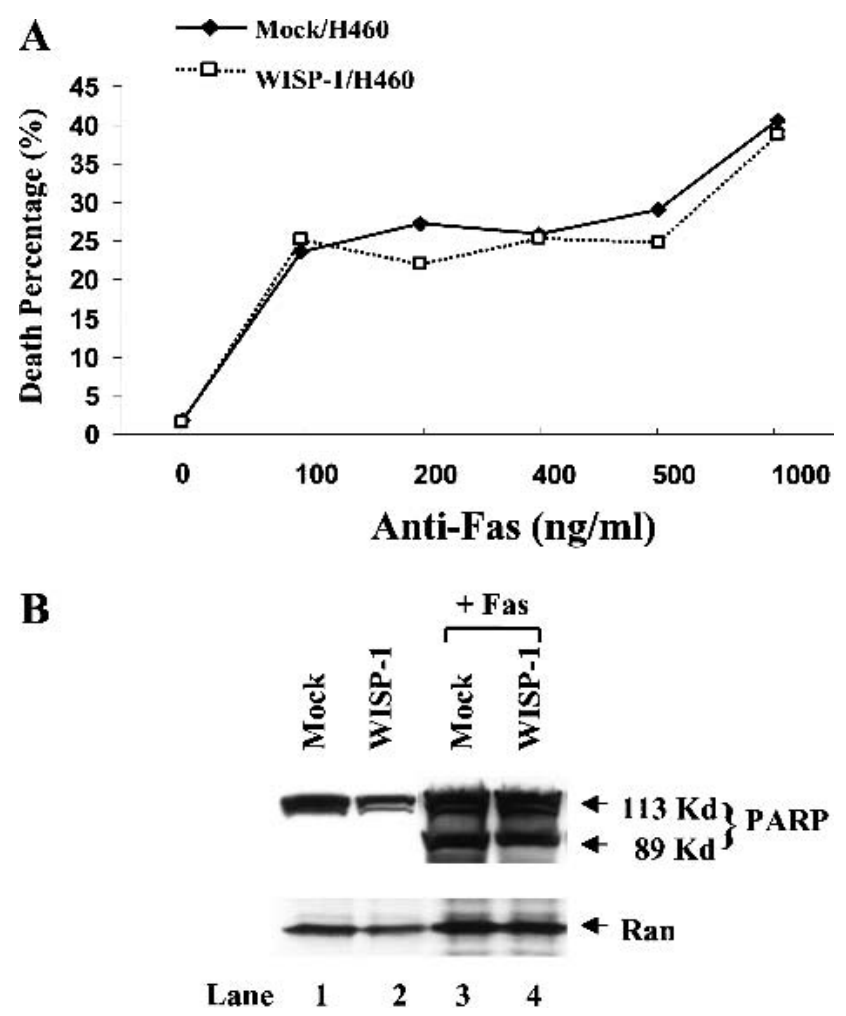

Figure 5. WISP-1 does not protect cells from Fas-induced apoptosis. (A) Vector or WISP-1-expressing H460 cells were split onto coverslips $20 \mathrm{~h}$ before being treated with anti-Fas monoclonal antibody $\mathrm{CH}-11$ at indicated concentrations for $30 \mathrm{~h}$. Cells were then fixed and stained with Hoechst stain for nuclei visualization. The percentages of apoptotic cells were calculated by counting $>500$ cells for each sample and scoring apoptotic cells with condensed staining compared with normal diffuse staining. $(B)$ Vector or WISP-1-expressing cells were treated with anti-Fas antibody for $30 \mathrm{~h}$. Whole cell extracts were then prepared and Western blot analysis was performed using antibody against PARP. Anti-Ran antibody is used for loading control.

(Levine 1997; Prives and Hall 1999). Therefore, to determine the mechanisms by which WISP-1 protects cells against apoptosis induced by DNA damage, we first examined whether WISP-1 inhibited cell death by inhibiting p53 activation following DNA damage. Vector alone or WISP-1-expressing cells were treated with $20 \mathrm{~J} / \mathrm{m}^{2}$ of UV irradiation or with $50 \mu \mathrm{M}$ of etoposide. Whole-cell lysates were prepared $24 \mathrm{~h}$ after treatment, and proteins were analyzed by an SDS-PAGE. p53 levels were measured by Western blotting with the DO-1 anti-p53 monoclonal antibody. The p53 levels in WISP-1-expressing cells were equal to or even higher than levels in vectorexpressing cells following DNA damage (Fig. 6A), suggesting that WISP-1 does not block the activation of p53 following damage to DNA. It is well established that DNA damage leads to phosphorylation of p53 at several N-terminal residues, including Ser 15, Ser 20, and Ser 37 , which appears to be important for stabilization the p53 protein (Shieh et al. 1997, 1999; Unger et al. 1999). We therefore tested whether p53 could be phosphorylated properly in the WISP-1-expressing cells. Phosphorylated p53 at Ser 15 was detected by an antibody that is specific for phospho-Ser 15 of p53. We found that Ser 15 of p53 was phosphorylated in both vector- and WISP-1-expressing cells following UV or etoposide treatment (Fig. 6A). Therefore, WISP-1 does not inhibit the activation or Ser 15 phosphorylation of $\mathrm{p} 53$.

To determine whether the activated p53 is transcriptionally functional, we examined the protein levels of three downstream target genes of p53, namely $m d m 2$, p21, which is known to be involved in cell cycle arrest, and Bax, which is believed to play a role in inducing apoptosis. Again, both control and WISP-1-expressing cells were treated with UV irradiation and etoposide. Twenty-four hours after treatment, whole-cell extracts were prepared and proteins were analyzed by Western blotting using antibodies against $\mathrm{p} 21$, Bax, or mdm2. We found that all three genes, $p 21, m d m 2$, and $B a x$, were activated in both control and WISP-1-expressing cells upon DNA damage (Fig. 6A,B; mdm2 results not shown). Similar results were obtained with the breast cancer cell line, MCF-7 cells. Taken collectively, these results dem-
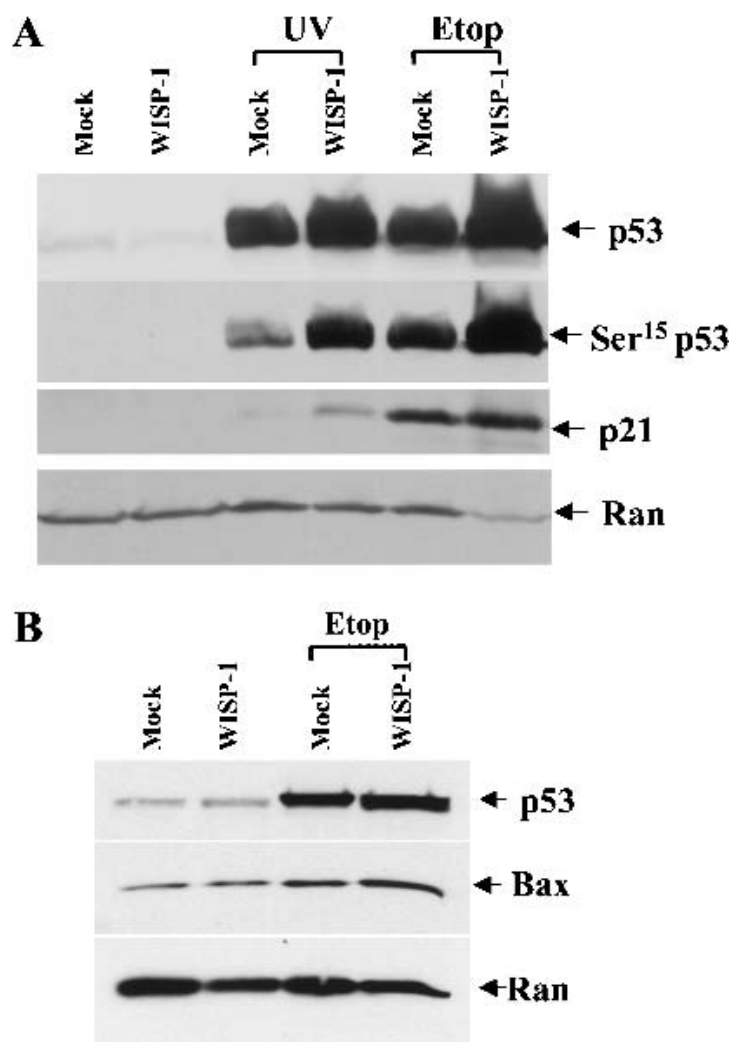

Figure 6. (A) Induction of $\mathrm{p} 53$ and $\mathrm{p} 21$ in WISP-1-expressing cells following DNA damage. Whole-cell extracts were prepared $24 \mathrm{~h}$ after exposure to $20 \mathrm{~J} / \mathrm{m}^{2}$ of UV-C light or $50 \mu \mathrm{M}$ of etoposide (Etop), and the samples were processed for Western blot analysis. Anti-Ran antibody is used to confirm that similar amounts of whole-cell extracts were analyzed. $(B)$ Bax was induced by p53 in response to DNA damage. Western analysis was performed as indicated in $A$ except using a polyclonal anti-Bax antibody. 
onstrate that WISP-1 inhibits cell death but not the induction of p53 following DNA damage, and interestingly the induced p53 protein is transcriptionally functional.

\section{WISP-1 inhibition of apoptosis requires Akt activity}

Akt promotes cell survival by regulating several key factors in the apoptotic machinery, including Bad, caspase9, forkhead transcription factor, GSK3 $\beta$ and NF-кB (for review, see Datta et al. 1999). This study demonstrated that WISP-1 can inhibit apoptosis in response to DNA damage and can induce phosphorylation and activation of Akt (Figs. 1,2). We therefore sought to determine whether Akt is required for WISP-1 inhibition of DNA damage-induced apoptosis. An Akt mutant that has a $\mathrm{K} 179 \mathrm{~A}$ substitution (Akt-KD) is a kinase dead mutant because it cannot bind ATP or phosphorylate substrates. In addition, this mutant has a dominant negative or inhibitory activity over the activation of endogenous Akt by insulin or other growth factors (Dudek et al. 1997). Akt-KD was delivered into vector alone or WISP-1-expressing $\mathrm{H} 460$ cells by retroviral infection, and several positive clones expressing $A k t-K D$ were identified and used for this experiment. Both floating and attached cells were collected after $30 \mathrm{~h}$ of etoposide treatment, and cells were subsequently stained with propidium iodide for FACS analysis. Again, treatment with etoposide induced a significant level of cell death in vector aloneexpressing cells $\left(\sim 24 \%\right.$ sub- $\left.\mathrm{G}_{1}\right)$ and $A k t-K D$-expressing cells $\left.(\sim 27 \% \text { sub-G })_{1}\right)$. WISP-1 was able to protect cells from etoposide-induced apoptosis in the WISP-1-expressing cells $\left(\sim 4 \%\right.$ sub- $\left.G_{1}\right)$, however, this protection was attenuated by Akt-KD in the cells expressing both WISP-1 and $A k t-K D(\sim 16 \% \text { sub-G })_{1}$ (Fig. 7). There may be two explanations for the fact that Akt-KD exerted an attenuation but not a complete abrogation of WISP-1 protection. First, the dominant negative effect of this $A k t-K D$ mutant may not be potent (Wang et al. 1999) enough to inhibit all the Akt activation induced by WISP-1; second, WISP-1 may also act on some other signaling pathways in addition to the Akt signaling pathway to inhibit p53mediated cell death. These results demonstrate that Akt activation was required at least in part for WISP-1 to prevent cells from undergoing apoptosis in response to DNA damage.

\section{WISP-1 up-regulates antiapoptotic protein Bcl- $X_{L}$}

The results above suggest that WISP-1 may act on some other signaling pathways in addition to the Akt signaling pathway to inhibit p53-mediated apoptosis. It is well established that members of the Bcl-2 family are major regulators of mitochondrial apoptotic events (Kroemer and Reed 2000). Expression of antiapoptotic members such as Bcl-2 and Bcl- $\mathrm{X}_{\mathrm{L}}$ prevents the redistribution of cytochrome $c$ in response to multiple death-inducing stimuli, whereas proapoptotic members such as Bax and Bak promote cytochrome $c$ release (Gross et al. 1999). It is possible that WISP-1 functions by regulating the Bcl-2 family of proteins. We have shown that Bax was moderately activated by p53 in response to DNA damage in both vector- and WISP-1-expressing cells (Fig. 6B). There was no change of the steady-state expression level of the Bak protein (data not shown). We therefore examined the ability of WISP-1 to activate antiapoptotic members of the Bcl-2 family. Whole-cell extracts were prepared $20 \mathrm{~h}$ after the cells expressing either vector alone or WISP-1 were treated with etoposide. The expression patterns of Bcl-2 and Bcl- $\mathrm{X}_{\mathrm{L}}$ were detected by Western blot analysis. There was no difference in Bcl-2 protein levels in both vector- and WISP-1-expressing H460 cells, suggesting that WISP-1 does not affect Bcl-2 expression (data not shown). However, endogenous levels of Bcl- $\mathrm{X}_{\mathrm{L}}$ were dramatically increased in the WISP-1-expressing cells, and the activation was independent of etoposide treatment (Fig. 8), indicating that WISP-1 up-regulates antiapoptotic $B c l-X_{L}$, which can protect the integrity of mitochondria, and thus inhibit apoptosis.

\section{Discussion}

WISP-1 belongs to the CCN family of growth factors that have been getting increasing attention lately because some of the family members have been reported to be
Figure 7. Akt activity is required for WISP-1 protection of cells from apoptosis. H460 cells expressing empty vector (mock), expressing WISP-1 (WISP-1), expressing both vector and Akt-KD (Akt-KD/mock) and expressing both WISP-1 and Akt-KD (Akt-KD/WISP-1) were treated with $50 \mu \mathrm{M}$ of etoposide for $30 \mathrm{~h}$. Cells were then stained with propidium iodide for FACS analysis. Apoptotic percentage was calculated by scoring sub- $G_{1}$ populations. Experiments were done with four different clones, three independent experiments, and duplicate samples.

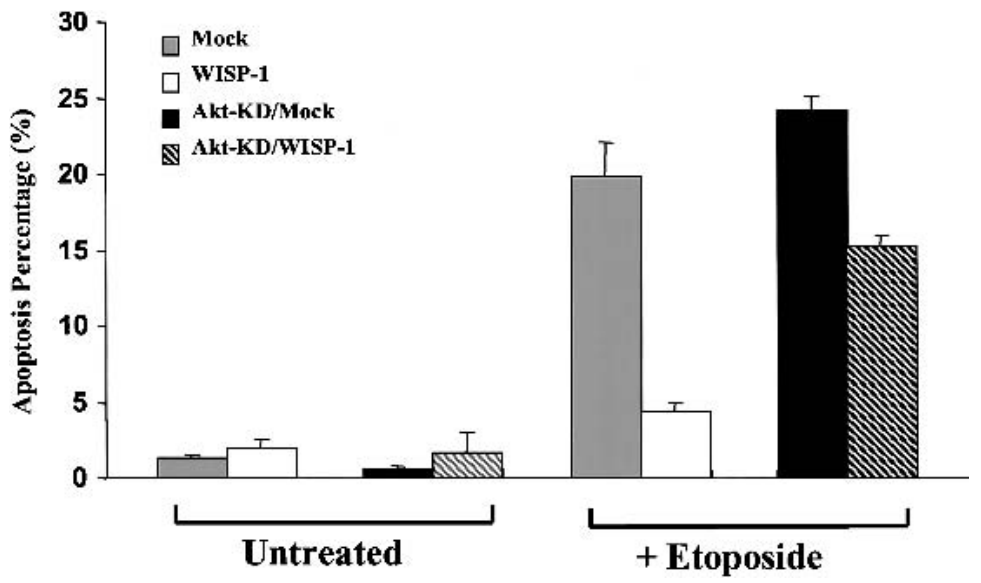




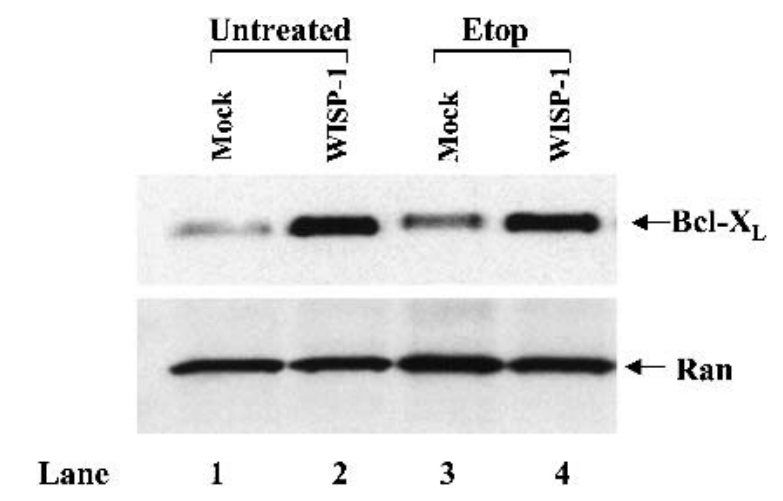

Figure 8. WISP-1 up-regulates antiapoptotic protein $\mathrm{Bcl}-\mathrm{X}_{\mathrm{L}}$. H460 cells expressing empty vector (mock) and expressing WISP-1 (WISP-1) were treated with $50 \mathrm{mM}$ of etoposide for $20 \mathrm{~h}$. Whole-cell extracts were then prepared and subjected to Western blot analysis using antibody against $\mathrm{Bcl}-\mathrm{X}_{\mathrm{L}}$.

involved in angiogenesis and tumorigenesis (AyerLelievre et al. 2001). After ascertaining that WISP-1 can accelerate cell growth and promote cellular tumorigenicity, this study demonstrated that WISP-1 activates the antiapoptotic Akt signaling pathway, inhibits the mitochondrial release of cytochrome $c$, up-regulates antiapoptotic protein $\mathrm{Bcl}-\mathrm{X}_{\mathrm{L}}$, and therefore prevents cells from undergoing apoptosis induced by DNA damage. Furthermore, the results showed that WISP-1 protects cells only from p53-dependent cell death. This is the first report that suggests that there is cross talk between the tumor suppressor protein $\mathrm{p} 53$ and WISP-1 signaling pathways.

The activation of Akt by WISP-1, the known activities of Akt, and the impact of the dominant negative Akt on apoptosis make it very likely that WISP-1 inhibits apoptosis by activating the antiapoptotic Akt kinase. Akt has been reported to block the release of cytochrome $c$ from mitochondria and thereby prevent initiation of the apoptotic cascade leading to activation of caspases (Kennedy et al. 1999; Gottlob et al. 2001). The results presented here show that WISP-1 can induce Akt activation and inhibit the mitochondrial release of cytochrome $c$ (Figs. $1,3 \mathrm{~B})$, thus indicating that WISP-1 activation of Akt may directly inhibit the cytochrome $c$ release from mitochondria (Fig. 9). It has also been demonstrated that Akt can promote cell survival of $\mathrm{T}$ lymphocyte and pre-mast cells through activation of antiapoptotic Bcl- $\mathrm{X}_{\mathrm{L}}$ (Jones et al. 2000; Tang et al. 2000). Bcl- $X_{L}$ has been reported to promote the survival of stress-damaged cells by maintaining mitochondrial integrity and function, and this antiapoptotic ability correlates with its ability to form heterodimers with proapoptotic members of the Bcl-2 family such as Bax (Sedlak et al. 1995; Kelekar et al. 1997). Proapoptotic Bax was moderately activated by p53 in response to DNA damage in both vector- and WISP-1expressing cells (Fig. 6B), yet only WISP-1 can protect cells from undergoing apoptosis induced by DNA damage. This study has demonstrated that WISP-1 up-regulates Bcl-X $\mathrm{X}_{\mathrm{L}}$ (Fig. 8). Thus, WISP-1 may inhibit p53-me- diated cell death by activating $\mathrm{Bcl}-\mathrm{X}_{\mathrm{L}}$, which antagonizes $\mathrm{Bax}$. In other studies, Bcl- $\mathrm{X}_{\mathrm{L}}$ has been shown to interact with caspase-9 and Apaf-1, resulting in the inhibition of caspase activation (Hu et al. 1998; Pan et al. 1998). Increased levels of Bcl- $\mathrm{X}_{\mathrm{L}}$ induced by WISP-1 may form inhibitory complexes with caspase-9, Apaf-1, and cytochrome $c$ after DNA damage, thus blocking apoptosis. Bcl- $\mathrm{X}_{\mathrm{L}}$ has also been shown to block DNA damage induced cytochrome $c$ release from mitochondria by binding to the cytochrome $c$ (Kharbanda et al. 1997), therefore it is possible that WISP-1 prevents cell death by inhibiting the release of mitochondrial cytochrome $c$ (Fig. 3B) through up-regulating Bcl- $\mathrm{X}_{\mathrm{L}}$ (Fig. 9). This is most consistent with the findings in this study.

Two lines of evidence demonstrate that WISP-1 only inhibits p53-dependent apoptosis. First, WISP-1 cannot protect H1299 cells, which do not have endogenous p53, from cell death following etoposide treatment (Fig. 4); Second, WISP-1 showed no protection against apoptosis in anti-Fas antibody treated cells (Fig. 5). Yet this study clearly demonstrated that cell death, but not p53 induction, was blocked in the WISP-1-expressing cells. It has been reported that p53-dependent apoptosis requires Apaf- 1 , which in turn requires release of cytochrome $c$ from mitochondria (Yoshida et al. 1998; Soengas et al. 1999). It appears then that WISP- 1 acts to attenuate p53mediated apoptosis by blocking activities downstream of the p53 pathway, such as release of cytochrome $c$ from

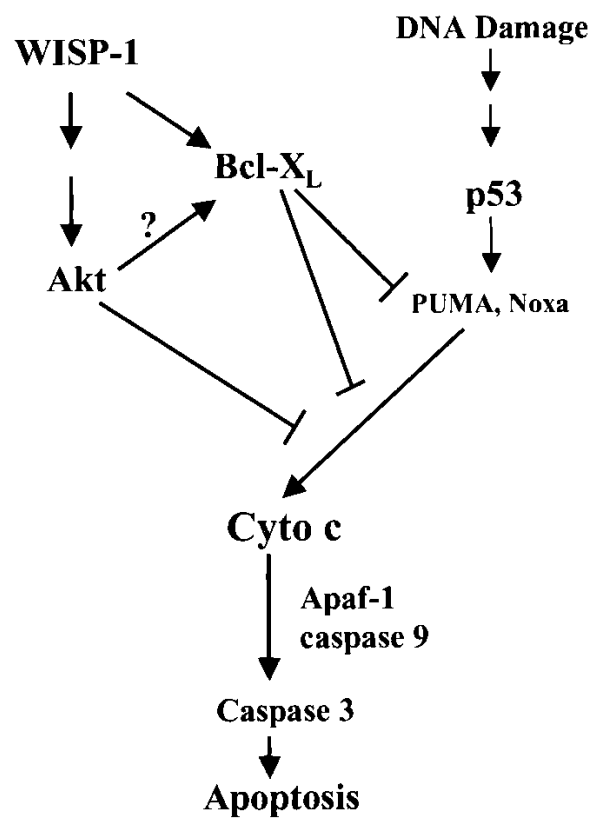

Figure 9. A schematic illustration of WISP-1 inhibition of p53mediated apoptosis in response to DNA damage. WISP-1 promotes cell survival by activating Akt, which may inhibit the release of cytochrome $c$ from mitochondria. WISP-1 also activates the antiapoptotic protein $\mathrm{Bcl}-\mathrm{X}_{\mathrm{L}}$, which in turn, through sequestering $\mathrm{p} 53$-mediated $\mathrm{BH} 3$ domain-only molecules such as PUMA or Noxa, prevents the mitochondrial release of cytochrome $c$, thus blocking the subsequent caspase cascade and eventual cell death. 
mitochondria. There are multiple pathways downstream of p53 that are potentially involved in the induction of apoptosis (Prives and Hall 1999). The p53 protein is a transcription factor; many experiments have demonstrated that transcriptional activation by p53 is critical for the induction of apoptosis (Gottlieb and Oren 1998). Moreover, several p53 target genes, such as Bax, Noxa, PERP, KILLER/DR5, p53IAP1, PIDD, or PUMA (Ryan et al. 2001), have been identified and are known to play a role in inducing apoptosis, although some of them such as Bax may have a redundant function because p53-induced death is not affected by its absence (Brady et al. 1996). Two of these p53 target genes, Noxa and PUMA, are both Bcl-2 homology (BH) 3 domain-only proteins, localize to the mitochondria, interact with antiapoptotic Bcl-2 family members such as Bcl-2 and Bcl- $\mathrm{X}_{\mathrm{L}}$ and function to induce cytochrome $c$ release, thereby activating caspase-9 and 3 (E. Oda et al. 2000; Nakano and Vousden 2001; Yu et al. 2001). The p53 protein is a major upstream determinant for stress-induced apoptosis via the mitochondrial cytochrome $c /$ caspase-9 pathway (Soengas et al. 1999), thus PUMA and Noxa provide a link between p53 and cytochrome $c$ release. It was reported very recently that antiapoptotic $\mathrm{Bcl}-2$ and $\mathrm{Bcl}-\mathrm{X}_{\mathrm{L}}$ act to sequester BH3 domain-only molecules such as Bad, Noxa and PUMA, thereby preventing the release of cytochrome $c$ from mitochondria and subsequent apoptosis (Cheng et al. 2001). This study has demonstrated that WISP-1 up-regulates the antiapoptotic Bcl- $\mathrm{X}_{\mathrm{L}}$ (Fig. 8). Therefore it seems likely that WISP-1 increases the level of $\mathrm{Bcl}-\mathrm{X}_{\mathrm{L}}$, which in turn combines with and suppresses the p53-inducible genes PUMA and Noxa. This in turn blocks cytochrome $c$ release, and apoptosis is halted even though p53 is activated (see Fig. 9). Whether Akt activation plays an important role in the increase in Bcl$\mathrm{X}_{\mathrm{L}}$ levels or adds to the antiapoptotic phenotype of Bcl$\mathrm{X}_{\mathrm{L}}$ remains to be elucidated (Fig. 9).

\section{Materials and methods}

\section{Cell culture, transfection, and retroviral infections}

NRK-49F, H460, H1299, and MCF-7 cell lines were maintained in DMEM supplemented with $10 \%$ FBS. WISP-1-expressing $\mathrm{H} 460$ and H1299 cell lines were established by transfection of HA- and Flag-epitope-tagged WISP-1 cDNA, whereas WISP-1expressing MCF7 cell lines were established by retroviral infections. Retroviral expression vector pBabe-puro was used to construct and express tagged human WISP-1 cDNA. Recombinant retroviruses were generated by transfecting the retroviral constructs into amphotropic PhoenixA packaging cells with lipofectamine (GIBCO BRL). Forty-eight hours posttransfection, retrovirus-containing supernatant was collected. Target cells were infected at about $40 \%$ confluence by adding the retrovirus-containing medium supplemented with $8 \mu \mathrm{g} / \mathrm{mL}$ polybrene. Infection medium was replaced with DMEM and 10\% FBS 10-16 h later. Cells were split into DMEM that contains $2.5 \mu \mathrm{g} / \mathrm{mL}$ puromycin at $48 \mathrm{~h}$ postinfection. Drug-resistant clones were picked and expanded. Total protein was extracted for IP-Western analysis to assess exogenous WISP-1 expression. A number of stable clones that express human WISP-1 at high levels were obtained for H460, H1299, and MCF7 cell lines.

\section{WISP-1-conditioned medium}

The hWISP-1-expressing NRK-49F cell line was established by retroviral infections as described previously (Xu et al. 2000) and was maintained in DMEM supplemented with $10 \%$ FBS and 2.5 $\mu \mathrm{g} / \mathrm{mL}$ puromycin. WISP-1-expressing and control cell lines were split into DMEM supplemented with $3 \%$ FBS, then WISP1 - and control-conditioned medium were collected $\geq 5 \mathrm{~d}$ later.

\section{DNA damage treatments}

Cells were seeded $24 \mathrm{~h}$ prior to treatment and were $50 \%-60 \%$ confluent at the time of treatment. WISP-1-expressing and control cells were treated with etoposide (Sigma) at a concentration of $50 \mu \mathrm{M}$ for $24 \mathrm{~h}$, or exposed for $10 \mathrm{sec}$ to a UVC lamp at 20 $\mathrm{J} / \mathrm{m}^{2}$ or irradiated by $30 \mathrm{~Gy}$ using a ${ }^{60} \mathrm{Co}$ source, then incubated for $24 \mathrm{~h}$ after the irradiation.

\section{Detection of apoptosis}

For FACS analysis $24 \mathrm{~h}$ or the indicated times after DNA damage, adherent and detached cells were combined and fixed overnight or longer with $80 \%$ ethanol in PBS at $-20^{\circ} \mathrm{C}$. After washing twice with PBS, cells were incubated for $1 \mathrm{~h}$ or longer with $1 \mathrm{~mL}$ of PBS containing $1 \mathrm{mg}$ of boiled RNaseA and $10 \mu \mathrm{g}$ of propidium iodide. A total of $5 \times 10^{5}$ cells were then analyzed in a flow cytometer (FACScalibur, BD).

For Hoechst staining, 125,000 cells were plated onto six-well plates where each well contained a microscope coverslip the day before the treatment with anti-Fas antibody. About $24 \mathrm{~h}$ after treatment, cells were gently washed with PBS, and fixed/permeabilized with freshly made $70 \%$ acetone $/ 30 \%$ methanol at $-20^{\circ} \mathrm{C}$ for $7 \mathrm{~min}$. Cells were stained with Hoechst 33258 for nuclei. The condensed DNA was determined by intense local staining of DNA in the nucleus compared with the diffuse staining of DNA in normal cells. The percentage of apoptotic cells was determined from cells containing normal DNA staining compared with cells with condensed DNA. A minimum of 500 cells was scored for each sample, and each experiment was performed in duplicate.

\section{Preparation of cytosolic extracts}

Cells were collected by centrifugation at $600 \mathrm{~g}$ for $5 \mathrm{~min}$ at $4^{\circ} \mathrm{C}$. The cell pellets were resuspended in five volumes of extraction buffer, containing $250 \mathrm{mM}$ sucrose, $20 \mathrm{mM}$ Hepes- $\mathrm{KOH}(\mathrm{pH}$ 7.5), $10 \mathrm{mM} \mathrm{KCl}, 1.5 \mathrm{mM} \mathrm{MgCl} 2,1 \mathrm{mM}$ sodium EDTA, $1 \mathrm{mM}$ sodium EGTA, $1 \mathrm{mM}$ DTT, and $0.1 \mathrm{mM}$ phenylmethylsulfonyl fluoride. After $30 \mathrm{~min}$ incubation on ice, cells were homogenized with a Teflon homogenizer (20 strokes). Cell homogenates were centrifuged twice at $750 \mathrm{~g}$ for $10 \mathrm{~min}$ at $4^{\circ} \mathrm{C}$. The supernatants were centrifuged at $10,000 \mathrm{~g}$ for $15 \mathrm{~min}$ at $4^{\circ} \mathrm{C}$, and the resulting mitochondria pellets were saved at $-80^{\circ} \mathrm{C}$. The supernatants of the $10,000 \mathrm{~g}$ spin were further centrifuged at $100,000 \mathrm{~g}$ for $90 \mathrm{~min}$ at $4^{\circ} \mathrm{C}$, and the resulting supernatants were designated as S-100 fractions.

\section{Western blot and antibodies}

All cells were harvested and lysed in extraction buffer $(20 \mathrm{mM}$ Tris- $\mathrm{HCl}$ at $\mathrm{pH} 7.4,150 \mathrm{mM} \mathrm{NaCl}, 1 \%$ Triton $\mathrm{X}-100,10 \%$ glycerol, $10 \mathrm{mM}$ EDTA, $1 \mathrm{mM} \mathrm{Na} \mathrm{VO}_{4}, 10 \mathrm{mM} \mathrm{NaF}, 10 \mathrm{mM}$ $\mathrm{Na}_{4} \mathrm{P}_{2} \mathrm{O}_{7}, 1 \mathrm{mM}$ PMSF, $1 \mu \mathrm{g} / \mathrm{mL}$ leupeptin, and $0.1 \mathrm{U} / \mathrm{mL}$ of aprotinin) and cleared by centrifugation for $10 \mathrm{~min}$ at $4^{\circ} \mathrm{C}$ to obtain whole-cell extracts. Each 20-50 $\mu \mathrm{g}$ sample of total protein was loaded onto $4 \%-15 \%$ gradient SDS-PAGE gels and 
blotted onto Hybond membranes (Amersham Pharmacia Biotech). Protein bands were visualized by chemiluminescent detection (ECL) (Amersham).

Anti-p53 monoclonal antibody (DO-1), anti-caspase-3, antiPARP and anti-Ran antibody were purchased from Santa Cruz. Anti-p21 antibody was purchased from Oncogene Science. AntiGSK3 $\beta$, anti-phospho-GSK3 $\beta$ (Ser 9), anti-Akt, anti-phosphoAkt (Ser 473) 4E2 monoclonal antibodies and anti-Bcl- $\mathrm{X}_{\mathrm{L}}$ were purchased from New England BioLabs. Anti-Fas monoclonal antibody $\mathrm{CH}-11$ was purchased from Kamiya Biomedical Company. Anti-Bax polyclonal antibody was purchased from Upstate Biotechnology. Anti-cytochrome $c$ monoclonal antibody (7H8) was purchased from BD Pharmingen. Anti-hWISP-1 polyclonal antibody was generated at Covance by using the variable domain of hWISP-1 (amino acids 173-213) linked to GST as an antigen. The polyclonal antibody was then purified by affinity chromatography using GST as the negative and the antigen as the positive immunoabsorbent.

\section{Acknowledgments}

We thank Lifeng Xu for her helpful suggestions and discussion. We also thank members of the Levine lab, Victor Jin, Ken Onel, and Christine Walsh for helpful suggestions; Michael Elowitz for his help with fluorescent microscopy; Mary Wang and Toula Stoffol for discussion; Angie Teresky for everything else. This work was supported by a grant from the National Institutes of Health to A.J.L. (CA87497) and by a fellowship from the Susan G. Komen Breast Cancer Foundation to F.S.

The publication costs of this article were defrayed in part by payment of page charges. This article must therefore be hereby marked "advertisement" in accordance with 18 USC section 1734 solely to indicate this fact.

\section{References}

Ashkenazi, A. and Dixit, V.M. 1998. Death receptors: Signaling and modulation. Science 281: 1305-1308.

Attardi, L.D., Reczek, E.E., Cosmas, C., Demicco, E.G., McCurrach, M.E., Lowe, S.W., and Jacks, T. 2000. PERP, an apoptosis-associated target of p53, is a novel member of the PMP22/gas3 family. Genes \& Dev. 14: 704-718.

Ayer-Lelievre, C., Brigstock, D., Lau, L., Pennica, D., Perbal, B., and Yeger, H. 2001. Report and abstracts on the first international workshop on the CCN family of genes. Mol. Pathol. 54: $105-120$.

Babic, A.M., Chen, C.C., and Lau, L.F. 1999. Fisp12/mouse connective tissue growth factor mediates endothelial cell adhesion and migration through integrin $\alpha \mathrm{v} \beta 3$, promotes endothelial cell survival, and induces angiogenesis in vivo. Mol. Cell. Biol. 19: 2958-2966.

Bates, S. and Vousden, K.H. 1999. Mechanisms of p53-mediated apoptosis. Cell. Mol. Life Sci. 55: 28-37.

Brady, H.J., Salomons, G.S., Bobeldijk, R.C., and Berns, A.J. 1996. T cells from bax $\alpha$ transgenic mice show accelerated apoptosis in response to stimuli but do not show restored DNA damage-induced cell death in the absence of p53. EMBO J. 15: 1221-1230.

Brigstock, D.R. 1999. The connective tissue growth factor/cysteine-rich 61/nephroblastoma overexpressed (CCN) family. Endocr. Rev. 20: 189-206.

Brunet, A., Bonni, A., Zigmond, M.J., Lin, M.Z., Juo, P., Hu, L.S., Anderson, M.J., Arden, K.C., Blenis, J., and Greenberg, M.E. 1999. Akt promotes cell survival by phosphorylating and inhibiting a Forkhead transcription factor. Cell 96: 857-868.

Cardone, M.H., Roy, N., Stennicke, H.R., Salvesen, G.S., Franke, T.F., Stanbridge, E., Frisch, S., and Reed, J.C. 1998. Regulation of cell death protease caspase-9 by phosphorylation. Science 282: 1318-1321.

Chen, C.C., Chen, N., and Lau, L.F. 2001. The angiogenic factors Cyr61 and connective tissue growth factor induce adhesive signaling in primary human skin fibroblasts. J. Biol. Chem. 276: 10443-10452.

Cheng, E.H., Wei, M.C., Weiler, S., Flavell, R.A., Mak, T.W., Lindsten, T., and Korsmeyer, S.J. 2001. Bcl-2, bcl-x(1) sequester bh3 domain-only molecules preventing bax- and bak-mediated mitochondrial apoptosis. Mol. Cell 8: 705-711.

Cross, D.A., Alessi, D.R., Cohen, P., Andjelkovich, M., and Hemmings, B.A. 1995. Inhibition of glycogen synthase kinase- 3 by insulin mediated by protein kinase B. Nature 378: 785-789.

Cryns, V. and Yuan, J. 1998. Proteases to die for. Genes \& Dev. 12: $1551-1570$.

Datta, S.R., Dudek, H., Tao, X., Masters, S., Fu, H., Gotoh, Y., and Greenberg, M.E. 1997. Akt phosphorylation of BAD couples survival signals to the cell-intrinsic death machinery. Cell 91: 231-241.

Datta, S.R., Brunet, A., and Greenberg, M.E. 1999. Cellular survival: A play in three Akts. Genes \& Dev. 13: 2905-2927.

Dedhar, S., Williams, B., and Hannigan, G. 1999. Integrin-linked kinase (ILK): A regulator of integrin and growth-factor signalling. Trends Cell. Biol. 9: 319-323.

Delcommenne, M., Tan, C., Gray, V., Rue, L., Woodgett, J., and Dedhar, S. 1998. Phosphoinositide-3-OH kinase-dependent regulation of glycogen synthase kinase 3 and protein kinase B/AKT by the integrin-linked kinase. Proc. Natl. Acad. Sci. 95: 11211-11216.

Di Cristofano, A. and Pandolfi, P.P. 2000. The multiple roles of PTEN in tumor suppression. Cell 100: 387-390.

Dudek, H., Datta, S.R., Franke, T.F., Birnbaum, M.J., Yao, R., Cooper, G.M., Segal, R.A., Kaplan, D.R., and Greenberg, M.E. 1997. Regulation of neuronal survival by the serinethreonine protein kinase Akt. Science 275: 661-665.

Giancotti, F.G. and Ruoslahti, E. 1999. Integrin signaling. Science 285: 1028-1032.

Gottlieb, T.M. and Oren, M. 1998. p53 and apoptosis. Semin. Cancer Biol. 8: 359-368.

Gottlob, K., Majewski, N., Kennedy, S., Kandel, E., Robey, R.B., and Hay, N. 2001. Inhibition of early apoptotic events by Akt/PKB is dependent on the first committed step of glycolysis and mitochondrial hexokinase. Genes \& Dev. 15: 14061418.

Gross, A., McDonnell, J.M., and Korsmeyer, S.J. 1999. BCL-2 family members and the mitochondria in apoptosis. Genes \& Dev. 13: 1899-1911.

Grzeszkiewicz, T.M., Kirschling, D.J., Chen, N., and Lau, L.F. 2001. CYR61 Stimulates human skin fibroblast migration through integrin $\alpha \mathrm{v} \beta 5$ and enhances mitogenesis through integrin $\alpha \mathrm{v} \beta 3$, independent of its carboxy-terminal domain. J. Biol. Chem. 276: 21943-21950.

$\mathrm{Hu}, \mathrm{Y} .$, Benedict, M.A., Wu, D., Inohara, N., and Nunez, G. 1998. Bcl-XL interacts with Apaf-1 and inhibits Apaf-1-dependent caspase-9 activation. Proc. Natl. Acad. Sci. 95: $4386-4391$.

Hu, Y., Benedict, M.A., Ding, L., and Nunez, G. 1999. Role of cytochrome c and dATP/ATP hydrolysis in Apaf-1-mediated caspase-9 activation and apoptosis. EMBO J. 18: 3586-3595.

Jedsadayanmata, A., Chen, C.C., Kireeva, M.L., Lau, L.F., and Lam, S.C. 1999. Activation-dependent adhesion of human platelets to Cyr61 and Fisp12/mouse connective tissue 
growth factor is mediated through integrin $\alpha(\operatorname{IIb}) \beta(3)$. J. Biol. Chem. 274: 24321-24327.

Jones, R.G., Parsons, M., Bonnard, M., Chan, V.S., Yeh, W.C., Woodgett, J.R., and Ohashi, P.S. 2000. Protein kinase B regulates $\mathrm{T}$ lymphocyte survival, nuclear factor $\mathrm{\kappa B}$ activation, and Bcl-X(L) levels in vivo. J. Exp. Med. 191: 1721-1734.

Kelekar, A., Chang, B.S., Harlan, J.E., Fesik, S.W., and Thompson, C.B. 1997. Bad is a BH3 domain-containing protein that forms an inactivating dimer with Bcl-XL. Mol. Cell. Biol. 17: 7040-7046.

Kennedy, S.G., Kandel, E.S., Cross, T.K., and Hay, N. 1999. Akt/ Protein kinase B inhibits cell death by preventing the release of cytochrome c from mitochondria. Mol. Cell. Biol. 19: 5800-5810.

Kharbanda, S., Pandey, P., Schofield, L., Israels, S., Roncinske, R., Yoshida, K., Bharti, A., Yuan, Z.M., Saxena, S., Weichselbaum, R., et al. 1997. Role for Bcl-xL as an inhibitor of cytosolic cytochrome C accumulation in DNA damage-induced apoptosis. Proc. Natl. Acad. Sci. 94: 6939-6942.

Kireeva, M.L., Lam, S.C., and Lau, L.F. 1998. Adhesion of human umbilical vein endothelial cells to the immediate-early gene product Cyr61 is mediated through integrin $\alpha \mathrm{v} \beta 3$. J. Biol. Chem. 273: 3090-3096.

Ko, L.J. and Prives, C. 1996. p53: Puzzle and paradigm. Genes \& Dev. 10: 1054-1072.

Kops, G.J., de Ruiter, N.D., De Vries-Smits, A.M., Powell, D.R., Bos, J.L., and Burgering, B.M. 1999. Direct control of the Forkhead transcription factor AFX by protein kinase B. $\mathrm{Na}$ ture 398: 630-634.

Kroemer, G. and Reed, J.C. 2000. Mitochondrial control of cell death. Nat. Med. 6: 513-519.

Lau, L.F. and Lam, S.C. 1999. The CCN family of angiogenic regulators: The integrin connection. Exp. Cell Res. 248: 44 57.

Levine, A.J. 1997. p53, the cellular gatekeeper for growth and division. Cell 88: 323-331.

Lin, Y., Ma, W., and Benchimol, S. 2000. Pidd, a new deathdomain-containing protein, is induced by p53 and promotes apoptosis. Nat. Genet. 26: 122-127.

Lowe, S.W. and Lin, A.W. 2000. Apoptosis in cancer. Carcinogenesis 21: 485-495.

Miyashita, T. and Reed, J.C. 1995. Tumor suppressor p53 is a direct transcriptional activator of the human bax gene. Cell 80: 293-299.

Nagata, S. and Golstein, P. 1995. The Fas death factor. Science 267: 1449-1456.

Nakano, K. and Vousden, K.H. 2001. PUMA, a novel proapoptotic gene, is induced by p53. Mol. Cell 7: 683-694.

Nunez, G., Benedict, M.A., Hu, Y., and Inohara, N. 1998. Caspases: The proteases of the apoptotic pathway. Oncogene 17: 3237-3245.

Oda, E., Ohki, R., Murasawa, H., Nemoto, J., Shibue, T., Yamashita, T., Tokino, T., Taniguchi, T., and Tanaka, N. 2000. Noxa, a BH3-only member of the Bcl-2 family and candidate mediator of p53-induced apoptosis. Science 288: 1053-1058.

Oda, K., Arakawa, H., Tanaka, T., Matsuda, K., Tanikawa, C., Mori, T., Nishimori, H., Tamai, K., Tokino, T., Nakamura, Y., et al. 2000. p53AIP1, a potential mediator of p53-dependent apoptosis, and its regulation by Ser-46-phosphorylated p53. Cell 102: 849-862.

Pan, G., O'Rourke, K., and Dixit, V.M. 1998. Caspase-9, Bcl-XL, and Apaf-1 form a ternary complex. I. Biol. Chem. 273: 5841-5845.

Pennica, D., Swanson, T.A., Welsh, J.W., Roy, M.A., Lawrence, D.A., Lee, J., Brush, J., Taneyhill, L.A., Deuel, B., Lew, M., et al. 1998. WISP genes are members of the connective tissue growth factor family that are up-regulated in wnt-1-transformed cells and aberrantly expressed in human colon tumors. Proc. Natl. Acad. Sci. 95: 14717-14722.

Persad, S., Attwell, S., Gray, V., Mawji, N., Deng, J.T., Leung, D., Yan, J., Sanghera, J., Walsh, M.P., and Dedhar, S. 2001. Regulation of protein kinase B/Akt-serine 473 phosphorylation by integrin-linked kinase: Critical roles for kinase activity and amino acids arginine 211 and serine 343. J. Biol. Chem. 276: 27462-27469.

Polakis, P. 1999. The oncogenic activation of beta-catenin. Curr. Opin. Genet. Dev. 9: 15-21.

Prives, C. and Hall, P.A. 1999. The p53 pathway. I. Pathol. 187: 112-126.

Ruoslahti, E. 1999. Fibronectin and its integrin receptors in cancer. Adv. Cancer Res. 76: 1-20.

Ryan, K.M., Phillips, A.C., and Vousden, K.H. 2001. Regulation and function of the p53 tumor suppressor protein. Curr. Opin. Cell. Biol. 13: 332-337.

Sedlak, T.W., Oltvai, Z.N., Yang, E., Wang, K., Boise, L.H., Thompson, C.B., and Korsmeyer, S.J. 1995. Multiple Bcl-2 family members demonstrate selective dimerizations with Bax. Proc. Natl. Acad. Sci. 92: 7834-7838.

Shieh, S.Y., Ikeda, M., Taya, Y., and Prives, C. 1997. DNA damage-induced phosphorylation of p53 alleviates inhibition by MDM2. Cell 91: 325-334.

Shieh, S.Y., Taya, Y., and Prives, C. 1999. DNA damage-inducible phosphorylation of p53 at $\mathrm{N}$-terminal sites including a novel site, Ser20, requires tetramerization. EMBO J. 18: 1815-1823.

Soengas, M.S., Alarcon, R.M., Yoshida, H., Giaccia, A.J., Hakem, R., Mak, T.W., and Lowe, S.W. 1999. Apaf-1 and caspase-9 in p53-dependent apoptosis and tumor inhibition. Science 284: 156-159.

Sonoda, Y., Watanabe, S., Matsumoto, Y., Aizu-Yokota, E., and Kasahara, T. 1999. FAK is the upstream signal protein of the phosphatidylinositol 3-kinase-Akt survival pathway in hydrogen peroxide-induced apoptosis of a human glioblastoma cell line. J. Biol. Chem. 274: 10566-10570.

Tanaka, M., Suda, T., Haze, K., Nakamura, N., Sato, K., Kimura, F., Motoyoshi, K., Mizuki, M., Tagawa, S., Ohga, S., et al. 1996. Fas ligand in human serum. Nat. Med. 2: 317-322.

Tang, X., Downes, C.P., Whetton, A.D., and Owen-Lynch, P.J. 2000. Role of phosphatidylinositol 3-kinase and specific protein kinase B isoforms in the suppression of apoptosis mediated by the Abelson protein-tyrosine kinase. J. Biol. Chem. 275: 13142-13148.

Unger, T., Juven-Gershon, T., Moallem, E., Berger, M., Vogt Sionov, R., Lozano, G., Oren, M., and Haupt, Y. 1999. Critical role for Ser20 of human p53 in the negative regulation of p53 by Mdm2. EMBO I. 18: 1805-1814.

Verdu, J., Buratovich, M.A., Wilder, E.L., and Birnbaum, M.J. 1999. Cell-autonomous regulation of cell and organ growth in Drosophila by Akt/PKB. Nat. Cell. Biol. 1: 500-506.

Wang, Q., Somwar, R., Bilan, P.J., Liu, Z., Jin, J., Woodgett, J.R., and Klip, A. 1999. Protein kinase B/Akt participates in GLUT4 translocation by insulin in L6 myoblasts. Mol. Cell. Biol. 19: 4008-4018.

Wu, G.S., Kim, K., and el-Deiry, W.S. 2000. KILLER/DR5, a novel DNA-damage inducible death receptor gene, links the p53-tumor suppressor to caspase activation and apoptotic death. Adv. Exp. Med. Biol. 465: 143-151.

$\mathrm{Xu}$, L., Corcoran, R.B., Welsh, J.W., Pennica, D., and Levine, A.J. 2000. WISP-1 is a Wnt-1- and $\beta$-catenin-responsive oncogene. Genes \& Dev. 14: 585-595.

Yoshida, H., Kong, Y.Y., Yoshida, R., Elia, A.J., Hakem, A., Hakem, R., Penninger, J.M., and Mak, T.W. 1998. Apaf1 is 
required for mitochondrial pathways of apoptosis and brain development. Cell 94: 739-750.

Yu, J., Zhang, L., Hwang, P.M., Kinzler, K.W., and Vogelstein, B. 2001. PUMA induces the rapid apoptosis of colorectal cancer cells. Mol. Cell 7: 673-682.

Zha, J., Harada, H., Yang, E., Jockel, J., and Korsmeyer, S.J. 1996. Serine phosphorylation of death agonist BAD in response to survival factor results in binding to 14-3-3 not BCL-X(L). Cell 87: 619-628.

Zhao, R., Gish, K., Murphy, M., Yin, Y., Notterman, D., Hoffman, W.H., Tom, E., Mack, D.H., and Levine, A.J. 2000. Analysis of p53-regulated gene expression patterns using oligonucleotide arrays. Genes \& Dev. 14: 981-993.

Zhou, B.P., Liao, Y., Xia, W., Spohn, B., Lee, M.H., and Hung, M.C. 2001. Cytoplasmic localization of p21Cip1/WAF1 by Akt-induced phosphorylation in HER-2/neu-overexpressing cells. Nat. Cell. Biol. 3: 245-252.

Zou, H., Henzel, W.J., Liu, X., Lutschg, A., and Wang, X. 1997. Apaf-1, a human protein homologous to C. elegans CED-4, participates in cytochrome c-dependent activation of caspase-3. Cell 90: 405-413. 


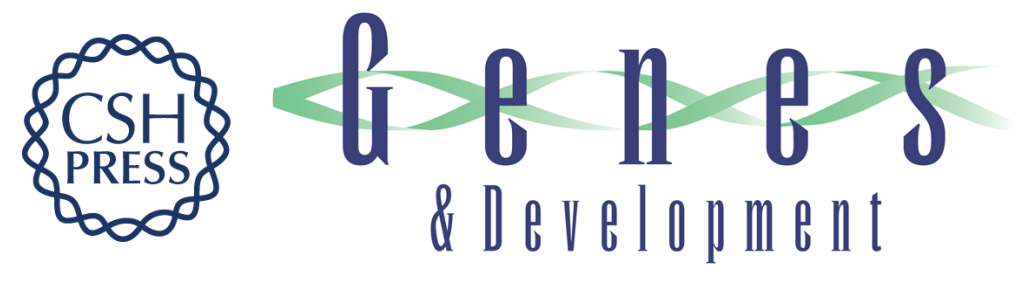

\section{WISP-1 attenuates p53-mediated apoptosis in response to DNA damage through activation of the Akt kinase}

Fei Su, Michael Overholtzer, Daniel Besser, et al.

Genes Dev. 2002, 16:

Access the most recent version at doi:10.1101/gad.942902

Related Content

References

\section{License}

Email Alerting Service

\section{Controlled by a WISP}

Sci. STKE January , 2002 2002: tw25

This article cites 70 articles, 37 of which can be accessed free at: http://genesdev.cshlp.org/content/16/1/46.full.html\#ref-list-1

Articles cited in:

http://genesdev.cshlp.org/content/16/1/46.full.html\#related-urls

Receive free email alerts when new articles cite this article - sign up in the box at the top right corner of the article or click here.

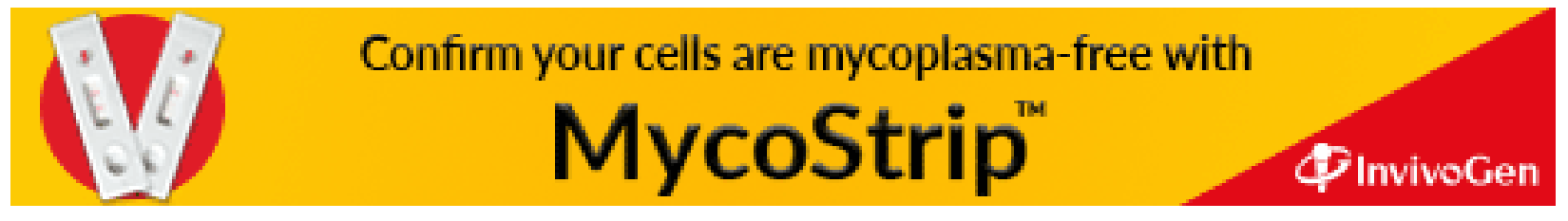

